\title{
Analisis Karakteristik Sosial Ekonomi Petani Lahan Gambut di Kabupaten Barito Kuala
}

\author{
Noor Husna Khairisa ${ }^{1}$, Junun Sartohadi ${ }^{2}$, M.Anggri Setiawan ${ }^{3}$ \\ ${ }^{1}$ Program Studi Geografi, Fakultas Ilmu dan Teknologi Kebumian, Universitas Halu Oleo \\ ${ }^{2}$ Fakultas Pertanian, Universitas Gadjah Mada \\ ${ }^{3}$ Fakultas Geografi, Universitas Gadjah Mada \\ e-mail:
}

\begin{abstract}
Abstrak: Pertambahan jumlah penduduk, peningkatan kebutuhan, perkembangan teknologi dan ilmu pengetahuan diikuti dengan perkembangan usaha peningkatan kesejahteraan penduduk mengakibatkan pemusatan perhatian lebih kepada fungsi sosial ekonomi dan pemanfaatan lahan gambut dibandingkan dengan fungsi ekologinya. Masyarakat lahan gambut pada umumnya bekerja sebagai petani yang merupakan pekerjaan yang diwariskan secara turun temurun sejak awal penggunaannya. Lahan gambut di Kabupaten Barito Kuala dominan digunakan sebagai lahan pertanian padi, perkebunan karet dan perkebunan kelapa sawit dengan jumlah penduduk yang bekerja pada sektor pertanian sebanyak 18.023 jiwa. Penelitian ini bertujuan untuk menganalisis karakteristik sosial ekonomi petani yang menggunakan lahan gambut untuk pertanian di Kabupaten Barito Kuala. Penelitian ini menggunakan metode survei. Sampel penelitian ditentukan dengan menggunakan Accidential Sampling. Metode deskriptif kuantitatif digunakan untuk menganalisis sosial ekonomi data petani yang dibagi menjadi 3 kelas data berdasarkan komoditas yang dominan diusahakan, yaitu padi, karet dan kelapa sawit. Hasil penelitian menunjukkan bahwa pengalaman usaha tani yang paling lama dimiliki oleh petani padi. Umur petani pada ketiga komoditas yang diusahakan adalah 45-59 tahun, anggota keluarga petani berkisar antara 2-6 orang. Petani memiliki tingkat pendidikan yang rendah, terutama petani padi, mereka dominan bahkan tidak lulus Sekolah Dasar (SD). Luas kepemilikan lahan adalah sedang (0,5 - 1 ha) dan luas ( $>1$ ha). Semua petani memiliki pendapatan rendah $(<1.500 .000$ Rupiah), sehingga petani perlu memiliki pekerjaan tambahan entah yang masih dalam maupun diluar sektor pertanian untuk memenuhi kebutuhan hidupnya. Kontribusi pendapatan dari pekerjaan lain pada keseluruhan pendapatan petani adalah sebesar $70 \%-91 \%$.
\end{abstract}

\section{Kata kunci: Petani, Lahan Gambut, Sosial-Ekonomi, Pertanian}

Abstract: The increase of population, demand, and development of technology and science, followed by development of efforts to increase the population's welfare resulted in focus on the socioeconomic functions and utilization of peatlands are more than its ecological functions. Local community in peatland area generally work as farmers, which is a job that has been passed down from generation to generation since the beginning of its use. Peatland in Barito Kuala Regency is widely used as agricultural land with a total population who work in the agricultural sector is 18,023 persons. This study aims to analyze the socio-economic characteristics of farmers who farm in peatland area in Barito Kuala Regency. This research used a survey method. Samples were determined by Accidental Sampling method. Descriptive quantitative method was used to analyze socio-economic data of farmers that are divided into 3 classes data based on dominant cultivated crop i.e. paddy, rubber and palm oil. The result shows that paddy farmers have the longest farming experience. Dominantly age of farmers in 3 cultivated crops are about 45-59 years, family member of farmer is about 2 until 6 persons. Farmers have low education level, especially paddy farmers, they even do not have elementary education. Land ownership areas are medium (0.5-1 acre) and large (> 1 acre). All farmers have low income $(<1.500 .000$ IDR) thus farmers have to do side job either off-farm or non-farm job to meet their daily need, contribution of side job in total income is about $70 \%-91 \%$.

Keywords: Farmer, Peatland, Socio-Economi, Agriculture 


\section{PENDAHULUAN}

Lahan gambut memiliki fungsi ekologi dan fungsi sosial ekonomi. Fungsi ekologi lahan gambut merupakan fungsi bawaan lahan gambut secara alami, yaitu sebagai media tumbuh tanaman, penyerap dan penyimpan air, tempat penyimpan karbon, pengendali banjir dan kekeringan, dan habitat flora dan fauna. Fungsi sosial ekonomi lahan gambut merupakan fungsi lahan gambut yang bermanfaat bagi manusia untuk memenuhi kebutuhan hidupnya, yaitu sebagai lahan pertanian, bahan bakar, lahan tempat tinggal, tempat rekreasi, penyedia produk hutan, penyedia ikan, bahan baku industri, dan sumber air (Phillips, 1998; Wibowo, 2009; Noor, 2010). Saat ini perhatian lebih banyak tertuju pada fungsi sosial ekonomi dan pemanfaatan lahan gambut diakibatkan oleh adanya pertambahan jumlah penduduk, peningkatan kebutuhan, dan perkembangan teknologi dan ilmu pengetahuan diikuti dengan perkembangan usaha peningkatan kesejahteraan penduduk.

Penggunaan lahan gambut merupakan perwujudan pemanfaatan lahan. Pada awal pemanfaatannya, lahan gambut di Indonesia digunakan untuk budidaya padi (Radjagukguk, 2000). Pemanfaatan gambut dimulai dengan cara yang sangat sederhana, yaitu dengan pembukaan hutan rawa di sekitar sungai dan pembuatan irigasi (Rina dan Noorginayuwati, 2013; Najiyati dkk, 2005). Pemanfaatan lahan gambut saat ini berkembang menjadi lebih beragam seperti pertanian tanaman pangan, pertanian tanaman holtikultura, perkebunan, pengembalaan kerbau rawa, hingga pada sektor pariwisata berupa taman nasional Penggunaan lahan paling dominan adalah lahan pertanian lahan gambut dengan luas mencapai 2.683 .844 ha (18\% dari seluruh luas gambut) yang dapat dirinci sebagai berikut: 1.562 .409 ha lahan perkebunan, 323.463 ha pertanian tanaman pangan, 456.857 ha kebun campuran, dan lahan seluas sawah 341.115 ha (Ritung dkk, 2011).

Karakteristik masyarakat yang khas dapat terbentuk di suatu area dengan suatu pemanfaatan lahan yang terjadi dalam waktu yang lama (Rahardjo, 2012). Masyarakat lahan gambut pada umumnya bekerja sebagai petani yang merupakan pekerjaan yang diwariskan secara turuntemurun. Pola usaha tani di lahan gambut ada empat, yaitu sistem usaha tani berbasis padi, sistem usaha tani berbasis komoditas holtikultura, sistem usaha tani berbasis tanaman perkebunan, dan sistem usaha tani campuran (Haryono dkk, 2013; Rina dan Noorginayuwati, 2013). Jumlah petani yang mengusahakan lahannya untuk tanaman pangan lebih dominan dan umumnya memiliki lahan seluas 1 - 2 ha, sedangkan jumlah petani yang mengusahakan lahannya untuk tanaman perkebunan dan holtikultura cukup sedikit mulai dari skala kecil hingga skala besar, mencapai ribuan hektar (Haryono dkk, 2013).

Kabupaten Barito Kuala merupakan salah satu kabupaten di Propinsi Kalimantan Selatan yang $40,54 \%$ wilayahnya merupakan lahan gambut (Bappeda, 2013). Lahan gambut di Kabupaten Barito Kuala merupakan bagian dari Cekungan Antiklinal Gambut Delta Barito yang terletak diantara Sungai Barito dan Sungai Kapuas (Arisanty, 2013). Penggunaan lahan pada Cekungan Antiklinal Gambut Delta Barito Tahun 2015, antara lain: hutan konversi, permukiman, belukar, perkebunan, dan sawah.

Penduduk di daerah penelitian dominan bekerja pada sektor pertanian sebanyak 18.023 jiwa, sedangkan penduduk yang bekerja di sektor nonpertanian sebanyak 8.503 jiwa (BPS, 2014). Berdasarkan banyaknya penduduk yang bekerja di bidang pertanian, maka penelitian ini bertujuan untuk mengetahui karakteristik petani lahan gambut di Kabupaten Barito Kuala berdasarkan 
komoditas yang diusahakan, yaitu padi, kelapa sawit dan karet.

\section{METODE PENELITIAN}

\subsection{Lokasi penelitian}

Lokasi penelitian merupakan Cekungan Antiklinal Gambut Delta Barito yang secara adiministrasi sebagian besar terletak di Kabupaten Barito Kuala (Kalimantan Selatan) dan sebagian yang lain terletak di Propinsi Kalimantan Tengah. Penelitian akan difokuskan pada Bagian Cekungan Antiklinal Gambut yang berada di Kabupaten Barito Kuala, meliputi 4 kecamatan, antara lain: Kecamatan Barambai, Kecamatan Tabukan, Kecamatan Marabahan, dan Kecamatan Belawang (Gambar 1).

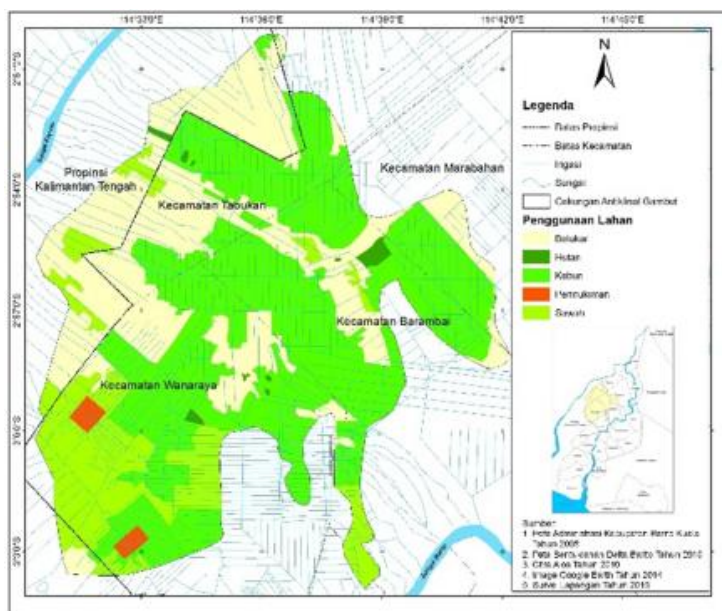

Gambar 1. Penggunaan Lahan di Daerah Penelitian

\subsection{Sampel penelitian}

Populasi penelitian adalah seluruh petani yang memanfaatkan lahan di lokasi penelitian. Karena tidak diketahui jumlah petani yang memanfaatkan lahan di daerha penelitian sehingga pengambilan sampel penelitian menggunakan metode Accidental Sampling. Sampel diambil berdasarkan petani yang ditemui di lokasi penelitian.

\subsection{Metode pengumpulan data}

Pengumpulan data dilakukan dengan menggunakan metode wawancara terstruktur. Wawancara dilakukan dengan menggunakan pedoman wawancara yang berisi daftar pertanyaan sesuai tujuan penelitian.

\subsection{Metode analisis data}

Data penelitian dianalisis dengan menggunakan metode deskiptif kuantitatif. Hasil pengumpulan data hasil wawancara berupa umur, tingkat pendidikan, jumlah anggota keluarga, lama pengalaman bertani, luas kepemilikan lahan, jenis pekerjaan lain, dan pendapatan petani, dijelaskan secara deskriptif, sehingga diperoleh gambaran umum karakteristik sosial ekonomi petani lahan gambut di Kabupaten Barito Kuala.

\section{HASIL DAN PEMBAHASAN}

3.1 Umur

Umur merupakan salah satu faktor yang berpengaruh pada kemampuan seseorang untuk melakukan aktivitas secara fisik saat bekerja dan saat melakukan kegiatan sehari-hari. Data umur petani pada tiap komoditas yang diusahakan disajikan pada Tabel 1.

Tabel 1. Umur Petani

\begin{tabular}{cccc}
\hline $\begin{array}{c}\text { Umur } \\
\text { tahun) }\end{array}$ & $\begin{array}{c}\text { Petani } \\
\text { Padi }\end{array}$ & $\begin{array}{c}\text { Petani } \\
\text { Kelapa Sawit }\end{array}$ & $\begin{array}{c}\text { Petani } \\
\text { Karet }\end{array}$ \\
\hline$<24$ & 2 & 0 & 1 \\
\hline $25-30$ & 5 & 2 & 4 \\
\hline $31-44$ & 12 & 6 & 5 \\
\hline $45-59$ & 18 & 8 & 10 \\
\hline$>60$ & 4 & 2 & 4 \\
\hline Jumlah & 41 & 18 & 24 \\
\hline
\end{tabular}

Sumber: Hasil Analisis, 2015

Penggunaan lahan di daerah penelitian sebagai sawah dan kebun karet sudah berlangsung cukup lama, berdasarkan hasil wawancara, petani padi dan karet merupakan petani generasi kedua dan ketiga, sedangkan petani kelapa sawit masih merupakan generasi pertama karena baru berlangsung dalam 10 tahun terakhir.

Smart dan Peaterson (1997) menyebutkan bahwa pada umur 31-44 tahun adalah tahap kemajuan dimana seseorang akan meningkatkat kualitas kerja. Petani padi yang berumur 31-44

$$
\text { April --- } 89
$$


tahun berusaha meningkatkan pendapatannya dengan menanam tanaman lain, seperti sawit atau palawija di bagian guludan sawah, mengalihfungsikan lahan sawahnya dengan komoditas lain, dan atau memiliki pekerjaan lain. Petani karet pada tahapan ini cenderung memilih memertahankan kualitas lahan dan hasil produksi. Pekerja yang berumur 45-59 tahun sudah berada pada tahap pemeliharaan dalam perkembangan karir (Smart dan Peaterson, 1997). Pada tahap umur 45-59 tahun, petani pada umumnya sudah cukup nyaman dengan pekerjaanya dengan kondisi finansial yang cinderung stabil, sehingga cinderung hanya memertahankan dan mengusahakan komoditas yang selama ini dia usahakan.

\subsection{Pendidikan}

Tingkat pendidikan petani berpengaruh pada cara pengumpulan dan pengolahan informasi yang didapat petani dalam pengambilan keputusan terkait dengan usaha pertaniannya. Semakin tinggi pendidikan petani, maka semakin mudah petani menerima pengetahuan dan teknologi baru, semakin tinggi kapasitas petani dalam mengelola lahan, serta semakin bijak keputusan yang akan diambil petani dalam kegiatan memertahankan kualitas lahan dalam jangka panjang dari segi ekonomi dan segi kelestarian lingkungan.

Tabel 2. Pendidikan Akhir Petani

\begin{tabular}{cccc}
\hline $\begin{array}{c}\text { Pendidikan } \\
\text { Akhir }\end{array}$ & $\begin{array}{c}\text { Petani } \\
\text { Padi }\end{array}$ & $\begin{array}{c}\text { Petani } \\
\text { Kelapa } \\
\text { Sawit }\end{array}$ & $\begin{array}{c}\text { Petani } \\
\text { Karet }\end{array}$ \\
\hline $\begin{array}{c}\text { Tidak } \\
\text { sekolah }\end{array}$ & 7 & 1 & 3 \\
\hline $\begin{array}{c}\text { Tidak tamat } \\
\text { SD }\end{array}$ & 12 & 3 & 5 \\
\hline Tamat SD & 10 & 7 & 12 \\
\hline SMP & 8 & 4 & 2 \\
\hline SMA & 4 & 3 & 2 \\
\hline Jumlah & 41 & 18 & 24 \\
\hline
\end{tabular}

Sumber: Hasil analisis, 2015

Terdapat hubungan antara tingkat pendidikan dan jenis komoditas yang diusahakan (Tabel 2). Pada umumnya tingkat pendidikan petani karet dan petani kelapa sawit lebih tinggi dibandingkan petani padi, hal ini disebabkan pengelolaan kebun karet dan kelapa sawit memerlukan kapasitas yang lebih tinggi.

Petani padi dominan tidak tamat SD, bahkan masih ada petani padi yang tidak sekolah. Pengelolaan sawah yang telah berlangsung secara turun termurun menjadi penyebab masyakarat merasa tidak perlu memiliki pendidikan yang tinggi untuk mengetahui cara bertani dengan baik, menurut mereka pengalaman yang didapat dari orang tua sudah cukup untuk dapat mengelola lahan dengan benar. Petani kelapa sawit yang tidak sekolah dan tidak tamat SD mengaku bahwa mengusahakan sawit karena terpengaruh dengan banyaknya petani yang mengusahakan kelapa sawit di lingkungannya dengan hasil panen yang cukup baik dan merasa pengusahaan kelapa sawit mudah dan dapat menghasilkan dalam jangka waktu yang relatif singkat.

\subsection{Pengalaman usaha tani}

Pengalaman bertani merupakan serangkaian proses pembelajaran bagaimana cara mengelola lahan dengan baik, melakukan tindakan pencegahan penurunan hasil produksi, mengetahui kelebihan dan kekurangan komoditas yang diusahakan, mengidentifikasi masalah yang terjadi di lahan, menganalisis perubahan yang akan terjadi dan membuat tindakan pemecahan masalah. Sehingga semakin lama pengalaman bertani, maka semakin banyak pengetahuan yang mereka miliki tentang cara pengelolaan terbaik pada komoditas yang mereka usahakan.

Tabel 3. Lama Pengalaman Usaha Tani

\begin{tabular}{cccc}
\hline $\begin{array}{c}\text { Pengalaman } \\
\text { (tahun) }\end{array}$ & $\begin{array}{c}\text { Petani } \\
\text { Padi }\end{array}$ & $\begin{array}{c}\text { Petani } \\
\text { Kelapa } \\
\text { Sawit }\end{array}$ & $\begin{array}{c}\text { Petani } \\
\text { Karet }\end{array}$ \\
\hline$<2$ & 2 & 6 & 3 \\
\hline $2-10$ & 7 & 12 & 16 \\
\hline$>10$ & 32 & 0 & 5 \\
\hline Jumlah & 41 & 18 & 24 \\
\hline
\end{tabular}


Sumber: Hasil analisis, 2015

Berdasarkan Tabel 3 diketahui bahwa petani yang memiliki pengalaman kurang dari dua tahun didominasi petani kelapa sawit, sedangkan petani dengan pengalaman lebih dari 10 tahun didominasi oleh petani padi. Petani padi pada umumnya memulai pengalaman bertani sejak kecil, saat membantu orang tua mereka menggarap lahan sawah, sehingga sudah sangat mahir dalam mengelola lahan sawah.

Perbedaan lama pengalaman petani padi dengan petani karet yang sama-sama dilakukan secara turun-temurun adalah petani karet dominan memiliki pengalaman berkebun selama 2-10 tahun. Hal ini dapat diartikan bahwa penggunaan lahan sawah ada lebih dulu dibandingkan lahan karet, selain itu pembudidayaan karet memerlukan modal yang besar dan waktu yang lama untuk masa pemanenan, sehingga tidak banyak petani yang memiliki modal yang cukup untuk membudidayakan tanaman karet. Petani padi dan karet dengan pengalaman kurang dari 2 tahun adalah pendatang lokal yang baru memulai usaha di daerah penelitian dan atau penduduk yang baru mendapat bantuan pemerintah untuk kembali mengusahakan lahannya. Petani kelapa sawit di daerah penelitian pada umumnya memiliki pengalaman 1-6 tahun karena kecenderungan penanaman kelapa sawit baru ada sejak 10 tahun terakhir.

\subsection{Jumlah Anggota Keluarga}

Jumlah anggota keluarga petani berpengaruh pada tingkat kesejahteraan petani. Jumlah anggota keluarga yang banyak membuat petani memiliki banyak tenaga kerja untuk mengelola lahan pertaniannya dan dapat memiliki banyak sumber pendapatan, disisi lain petani memiliki beban yang tinggi dalam hal pemenuhan kebutuhan.

Tabel 4 menunjukkan bahwa pada umumnya petani memiliki keluarga kecil dengan jumlah anggota keluarga kurang dari 4 orang, sehingga beban tanggungan pengeluaran tidak terlalu besar. Petani dengan jumlah anggota keluarga lebih dari 4 tidak bekerja sendiri, namun dibantu oleh anggota keluarga dalam kegiatan menggarap lahan atau pekerjaan sampingan baik off-farm maupun nonfarm.

Tabel 4. Jumlah Anggota Keluarga Petani

\begin{tabular}{cccc}
\hline $\begin{array}{c}\text { Jumlah } \\
\text { Anggota } \\
\text { Keluarga } \\
\text { (jiwa) }\end{array}$ & $\begin{array}{c}\text { Petani } \\
\text { Padi }\end{array}$ & $\begin{array}{c}\text { Petani } \\
\text { Kelapa } \\
\text { Sawit }\end{array}$ & $\begin{array}{c}\text { Petani } \\
\text { Karet }\end{array}$ \\
\hline$\leq 4$ & 31 & 12 & 18 \\
\hline $5-6$ & 7 & 4 & 6 \\
\hline$\geq 7$ & 3 & 2 & 0 \\
\hline Jumlah & 41 & 18 & 24 \\
\hline
\end{tabular}

Sumber: Hasil analisis, 2015

\subsection{Luas Lahan Usaha Tani}

Salah satu faktor dalam penentuan besar penghasilan dan kesejahteraan petani adalah luas lahan usaha tani. Semakin luas lahan yang digarap, maka makin besar pendapatan petani. Luas lahan usaha tani di daerah penelitian dianalisis berdasarkan klasifikasi luas lahan oleh Supriana (2009), yaitu lahan sempit $(<0,5$ ha), lahan sedang (0,5-1 ha) dan lahan luas (>1 ha).

Tabel 5. Luas Lahan Usaha Tani

\begin{tabular}{cccc}
\hline $\begin{array}{c}\text { Luas } \\
\text { lahan (ha) }\end{array}$ & $\begin{array}{c}\text { Petani } \\
\text { Padi }\end{array}$ & $\begin{array}{c}\text { Petani } \\
\text { Kelapa } \\
\text { Sawit }\end{array}$ & $\begin{array}{c}\text { Petani } \\
\text { Karet }\end{array}$ \\
\hline$<0,5$ & 11 & 3 & 6 \\
\hline $0,5-1$ & 18 & 4 & 10 \\
\hline$>1$ & 12 & 11 & 8 \\
\hline Jumlah & 41 & 18 & 24 \\
\hline
\end{tabular}

Sumber: Hasil analisis, 2015

Hasil analisis data pada Tabel 5 menunjukkan bahwa 30 petani padi dan 18 petani karet memiliki luas lahan 0,5-1 ha (sedang) hingga $>1$ ha (luas), sedangkan 11 petani kelapa sawit memiliki lahan $>1$ ha. Hal ini menandakan bahwa petani kelapa sawit adalah petani yang memiliki modal yang besar. Petani kelapa sawit mengambil keputusan untuk mengusahakan atau mengalihfungsikan lahan sawahnya untuk menanam kelapa 
sawit karena mereka telah melihat kenyataan bahwa petani kelapa sawit sebelumnya telah dinilai cukup berhasil dalam meningkatkan kesejahteraan.

\subsection{Pendapatan Petani}

Besar pendapatan petani di daerah penelitian dianalisis berdasarkan klasifikasi besar pendapatan oleh BPS, yaitu golongan pendapatan sangat tinggi (Rp. 3.500.000/ bulan), golongan pendapatan tinggi (Rp. 2.500.000 - Rp. $3.500 .000 /$ bulan), golongan pendapatan (Rp. 1.500.000 - Rp. 2.500.000/ bulan) dan golongan pendapatan rendah (Rp. $1.500 .000 /$ bulan).

Tabel 6. Besar Pendapatan Petani

\begin{tabular}{cccc}
\hline $\begin{array}{c}\text { Pendapatan } \\
\text { (Rp/Bulan) }\end{array}$ & $\begin{array}{c}\text { Petani } \\
\text { Padi }\end{array}$ & $\begin{array}{c}\text { Petani } \\
\text { Kelapa } \\
\text { Sawit }\end{array}$ & $\begin{array}{c}\text { Petani } \\
\text { Karet }\end{array}$ \\
\cline { 1 - 1 }$>3.500 .000$ & 8 & 3 & 5 \\
\hline $\begin{array}{c}2.500 .000- \\
3.500 .000\end{array}$ & 5 & 4 & 1 \\
\hline $\begin{array}{c}1.500 .000- \\
2.500 .000\end{array}$ & 4 & 5 & 4 \\
\hline$<1.500 .000$ & 24 & 6 & 14 \\
\hline Jumlah & 41 & 18 & 24 \\
\hline
\end{tabular}

Sumber: Hasil analisis, 2015

Pada Tabel 6 diketahui bahwa sebagian besar petani disemua komoditas memiliki penghasilan kurang dari 1.500.000 Rp/bulan. Faktor yang memengaruhi banyaknya petani berpenghasilan rendah, antara lain; petani hanya mengusahakan satu jenis komoditas, luas lahan yang sempit, tanaman masih masa tanaman belum menghasilkan (TBM) pada kebun karet dan kelapa sawit, petani tidak memiliki pekerjaan lain, dan rendahnya penghasilan dari pekerjaan lain baik bidang off-farm maupun non-farm.

$$
\text { Pekerjaan off-farm yang }
$$
memberikan penghasilan rendah, yaitu buruh tani yang bekerja hanya pada saat musim tanam dan musim panen dengan upah sebanyak Rp. 35.000 untuk setengah hari ( \pm 6 jam) dan Rp. 50.000 pada setiap luas lahan satu borongan $(0,0289$ ha), tenaga bantu membuka lahan dengan upah $50.000 \mathrm{Rp} /$ hari atau $20.000 \mathrm{Rp} /$ borongan, 92 --- April upah dari pekerjaan membersihkan rumput berkisar antara 25.000-30.000 Rp/hari, pembuat tukungan (petak-petak tanah dengan ukuran $1 \mathrm{~m}^{3}$ yang dipadatkan dan dibuat lebih tinggi dari daerah sekitarnya untuk menanam tanaman perkebunan) dengan upah 5.000-7.000/tukungan, pengrajin tikar purun dengan keuntungan $2.500 \mathrm{Rp} /$ tikar dan pekerja harian lepas (PHL) perusahaan kebun karet sebagai pemelihara tanaman dengan upah 52.000/hari namun tidak bekerja setiap hari. Pekerjaan non-farm yang memberikan penghasilan rendah, yaitu jasa pijat $50.000 \mathrm{Rp} /$ orang, pedagang warung klontong dengan keuntungan 500.000$600.000 \mathrm{Rp} / \mathrm{bulan}$, pencari ikan dengan pendapatan tidak menentu berkisar antara 20.000-120.000 Rp/hari, dan jasa asah batu akik dengan upah rata-rata 500.000/bulan.

Petani berpenghasilan sedang hingga sangat tinggi adalah petani yang memiliki lahan yang sedang $(0,5-1$ ha) hingga luas (>1 ha), memiliki pekerjaan lain dengan penghasilan yang besar, memiliki kebun sawit atau karet dengan tanaman yang sudah pada masa menghasilkan (TM), dan mengusahakan lebih dari satu komoditas seperti padikaret, padi-kelapa sawit, karet-kelapa sawit, padi-kelapa sawit-karet dan penanaman komoditas lain. Komoditas lain yang diusahakan petani berpenghasilan sedang-sangat tinggi adalah tanaman sayuran seperti kacang panjang, terong, daun bawang, dan cabai; tanaman palawija seperti singkong; tanaman buah seperti nanas, pisang, jambu, jeruk, rambutan, semangka, dan nangka.

$$
\text { Pekerjaan off-farm yang }
$$

memberikan penghasilan tinggi di daerah penelitian, yaitu: PHL di perusahaan kebun kelapa sawit dengan upah sebagai pemelihara tanaman 53.000/hari dan upah sebagai pemanen sawit berkisar 70.00077.000/hari; dan buruh penyadap karet dengan upah separuh dari hasil panen karet. Pekerjaan non-farm yang memberikan penghasilan tinggi, yaitu PNS, satpam, tukang bangunan, supir, dan 
peternak dengan penghasilan lebih dari 3.000.000 Rp/bulan.

\subsection{Jenis Pekerjaan Lain Petani}

Petani melakukan pekerjaan sampingan untuk meningkatkan pendapatan dan mencukupi kebutuhan rumah tangganya. Pekerjaan lain petani berdasarkan bidang pekerjaannya dibagi menjadi 2, yaitu; off-farm dan non-farm. Pekerjaan off-farm adalah pekerjaan yang dilakukan petani dibidang pertanian, selain menggarap lahannya sendiri. Pekerjaan non-farm adalah pekerjaan di luar bidang pertanian

Tabel 7. Jenis Pekerjaan Lain yang dilakukan Petani

\begin{tabular}{cccc}
\hline $\begin{array}{c}\text { Pekerjaan } \\
\text { lain }\end{array}$ & $\begin{array}{c}\text { Petani } \\
\text { Padi }\end{array}$ & $\begin{array}{c}\text { Petani } \\
\text { Kelapa } \\
\text { Sawit }\end{array}$ & $\begin{array}{c}\text { Petani } \\
\text { Karet }\end{array}$ \\
\hline Off farm & 17 & 6 & 8 \\
\hline Non-farm & 12 & 8 & 8 \\
\hline Tidak Bekerja & 12 & 4 & 8 \\
\hline Jumlah & 41 & 18 & 24 \\
\hline
\end{tabular}

Sumber: Hasil analisis, 2015

Petani yang tidak melakukan pekerjaan lain adalah petani yang berumur lebih dari 60 tahun dan petani yang merasa sudah cukup dengan mengolah lahan pertaniannya. Alasan lain bagi petani karet tidak memiliki pekerjaan lain adalah hasil karet yang sudah cukup untuk memenuhi kebutuhan rumah tangga dan sistem upah pemanenan karet yang tinggi. Sistem upah pemanenan karet sebanyak setengah dari hasil pejualan karet setiap kali panen, oleh karena itu banyak petani karet yang tidak melakukan pekerjaan lain agar pemanenan karet dapat dikerjakan sendiri dan menghasilkan pendapatan yang optimal.

Rata-rata kontribusi pendapatan offfarm dan non-farm pada keseluruhan pendapatan petani padi adalah sebesar $70 \%$ dan $72 \%$. Pendapatan lain dibutuhkan oleh para petani padi karena sebagian atau seluruh hasil panen padi digunakan untuk dikonsumsi sendiri dan petani seringkali merasa kesulitan keuangan pada masa pemeliharaan padi yang berlangsung selama 8-9 bulan.

Persentase rata-rata kontribusi pendapatan pekerjaan lain bagi petani karet dan kelapa sawit dari pekerjaan lain sangat tinggi, dari kegiatan off-farm sebesar 91\% dan dari kegiatan non-farm petani karet sebesar $88 \%$, sedangkan kontribusi on farm untuk petani kelapa sawit hanya sebesar 54\%. Kontribusi pendapatan yang tinggi dari pekerjaan lain pada petani karet dan petani kelapa sawit disebabkan sebagian besar kebun mereka masih dalam masa TBM, lahan kebun yang sempit atau pendapatan pada kegiatan off-farm cukup besar.

\section{KESIMPULAN}

Terdapat beberapa kesimpulan dari penelitian ini, antara lain: sebagian besar petani berumur 45-59 tahun, petani padi memiliki tingkat pendidikan lebih rendah dibanding petani kelapa sawit kelapa dan karet kerena pengetahuan bertani padi sudah didapat dari generasi sebelumnya oleh sebab itu pula pada umumnya petani padi memiliki pengalaman bertani lebih dari 10 tahun. Dari 83 sampel, hanya 5 petani yang memiliki jumlah keluarga lebih dari 7 orang. Lahan yang diusahakan untuk padi dan karet dominan seluas 0,5-1 ha, sedangkan untuk kelapa sawit lebih dari 1 ha. Petani disemua komoditas masih memiliki pendapatan kurang dari Rp. 1.500.000 per bulan untuk itu petani memiliki pekerjaan sampingan dibidang pertanian, maupun diluar bidang pertanian dengan kontribusi rata-rata berkisar antara $70-91 \%$ dari total pendapatan.

\section{DAFTAR PUSTAKA}

Arisanty, D. 2013. Morphodynamic of Barito Delta, Southern Kalimantan, [Disertasi]. Yogyakarta: Universitas Gadjah Mada

Badan Perencanaan Pembangunan Daerah Barito Kuala. 2013. Rencana Tata Ruang Wilayah (RTRW) Kabupaten Barito Kuala 2011 - 2031. 
Marabahan: Badan Perencanaan Pembangunan Daerah Barito Kuala

BPS. 2014. Kabupaten Barito Kuala dalam Angka 2014. Marabahan: Badan Pusat Statistik

Haryono, Muhammad Noor, Haris Syahbuddin, dan Muhrizal Sarwani. 2013. Lahan Rawa: Penelitian dan Pengembangan. Bogor: Badan Penelitian dan Pengembangan Pertanian

Najiyati, Sri., Lili Muslihat, dan I Nyoman N Suryadiputra. 2005. Panduan Pengelolaan Lahan Gambut untuk Pertanian Berkelanjutan. Bogor: Wetlands International - Indonesia Program

Noor, Muhammad. 2010. Lahan Gambut (Pengembangan, Konservasi dan Perubahan Iklim). Yogyakarta: Gadjah Mada University Press

Phillips, Victor D. 1998. Peatswam Ecology and Sustainable Development in Borneo. Jurnal Biodiversity and Conservation Vol. 7, p. 651-671

Radjagukguk, Bostang. 2000. Perubahan Sifat Fisik dan Kima Tanah Gambut Akibat Reklamasi Lahan Gambut Untuk Pertanian. Jurnal Ilmu Tanah dan Lingkungan. Vol. 2, No. 1, p.1-15.
Rahardjo. 2014. Pengantar Sosiologi Pedesaan dan Pertanian. Yogyakarta: Gadjah Mada University Press

Rina, Yanti dan Noorginayuwati. 2013. Sosial Ekonomi Petani di Lahan Gambut dalam Lahan Gambut: Pemafaatan dan Pengembanganya untuk Pertanian. Yogyakarta: Kanisius

Ritung, S., Wahyunto, dan K. Nugroho. 2012. Karakteristik dan sebaran lahan gambut di Sumatera, Kalimantan dan Papua. Prosiding Seminar Nasional Pengelolaan Lahan Gambut Berkelanjutan (h. 47-62). Bogor: Balai Besar Penelitian dan Pengembangan Sumberdaya Lahan Pertanian, Badan Penelitian dan Pengembangan Pertanian, Kementerian Pertanian

Smart, R \& Peterson, C. 1997. Super's Career Stages and the Decision to Change Careers. Journal of Vocational Behavior Vol 51. No.3, p.358-374

Supriana, T. 2009. Pengantar Ekonometrika Aplikasi dalam Bidang Ekonomi Pertanian. Medan: Universitas Sumatera Utara

Wibowo, Ari. 2009. Peran Lahan Gmabut dalam Perubahan Iklim Global. Jurnal Tekno Hutan Tanaman Vol.2, No.1. p. $19-28$ 